\title{
The main potentialities of resveratrol for drug delivery systems
}

\author{
Joana Ruivo ${ }^{1}$, Cátia Francisco ${ }^{2}$, Rita Oliveira ${ }^{1}$, Ana Figueiras ${ }^{2, * *}$ \\ ${ }^{1}$ Faculty of Health Sciences, University of Fernando Pessoa, Porto, Portugal, ${ }^{2}$ Faculty of Pharmacy, University of Coimbra, \\ Coimbra, Portugal
}

\begin{abstract}
Resveratrol (RSV), a natural polyphenol found in grapes, was found to be effective in the prevention and therapy of several diseases, however, it does have unfavourable physicochemical properties. In this context, an increasing number of studies have aimed at developing novel therapeutic systems for its delivery to overcome these disadvantages. This review focuses on the mechanisms of action and therapeutic applications. Finally, it also describes some tested formulations for RSV administration, controlled release and targeting, developed with the purpose of increasing RSV bioavailability.
\end{abstract}

Uniterms: Nutraceuticals. Natural polyphenols. Resveratrol/mechanisms of action. Resveratrol/ therapeutic applications. Resveratrol/delivery systems.

O resveratrol (RSV) é um polifenol natural encontrado nas uvas, que se mostrou eficaz na prevenção e terapia de várias doenças. No entanto, apresenta propriedades físico-químicas desfavoráveis. Neste contexto, um número cada vez maior de estudos visando ao desenvolvimento de novos sistemas terapêuticos para a sua liberação vem sendo desenvolvido no sentido de ultrapassar estas desvantagens. Esta revisão discorre sobre os mecanismos de ação e aplicações terapêuticas do RSV. Finalmente, são abordadas algumas formulações de liberação controlada e vetorizada, testadas para administração do RSV, desenvolvidas com a finalidade de aumentar a biodisponibilidade do RSV.

Unitermos: Nutracêuticos. Polifenóis naturais. Resveratrol/mecanismo de ação. Resveratrol/aplicações terapêuticas. Resveratrol/sistemas de liberação.

\section{INTRODUCTION}

The term nutraceutical (a combination of the terms 'nutrient' and 'pharmaceutical') is commonly given to dietary supplements which provide a concentrated dosage of a bioactive compound present in food, supplying higher dosages than those obtained from normal nutritional values in foods, and available in normal pharmaceutical forms (pills, powders, capsules, vials, extracts etc.) (Espín, García-Conesa, Tomás-Barberán, 2007). These products, intended for health promotion through disease prevention and/or treatment, can be divided into several classes, among which pro- and prebiotics, sulphured and nitrogenized foods, antioxidant vitamins, polyunsaturated fatty acids, oligosaccharides and polyphenols are of

\footnotetext{
*Correspondence: A. Figueiras. Faculdade de Farmácia. Universidade de Coimbra. Pólo das Ciências da Saúde. Azinhaga de Santa Comba. 3000-548 Coimbra. E-mail: rfigueiras@ff.uc.pt
}

particular interest (Moraes, Colla, 2006).

Plants, including food plants (vegetables and fruits), synthesize a wide array of chemical compounds, important in serving a variety of ecological functions that not only enhance the plant's survivability, but may also be responsible for a multitude of beneficial effects reported for health-related bioactivities (Joseph et al., 2008; Svobodová, Psotová, Walterová, 2003). In these terms, the resultant chemical compounds of the plant's primary and secondary cellular metabolism may be applied in the vast health-related arsenal, also bearing in mind the global resurgence in both medicine and natural cosmetics, in great part due to society's demands for options in ecological, safe and economic techniques.

More accurately, polyphenols, as 'secondary' chemical compounds, represent molecules exhibiting a common phenol structure, with a benzenic nucleus aromatic ring linked to at least one hydroxyl $\left(\mathrm{OH}^{-}\right)$group, free or belonging to esters, ethers or heterosides. These 
compounds, not synthesized by humans, are present in the daily diet, such as fruits, vegetables, cereals and drinks (tea, coffee and wine), especially in the Mediterranean diet. They represent serious candidates for the prevention of many pathologic states, as for example photoaging and cancer; this is essentially associated to their antioxidant activity (Moraes, Colla, 2006; Proença da Cunha, 2005; Svobodová, Psotová, Walterová, 2003).

Experimental studies support their preventive role in several diseases, in which oxidative stress seems to represent the principal and important precipitating factor. Resveratrol (RSV), a polyphenol and stilbene derivative, represents a naturally occurring triphenolic phytoalexin (Figure 1), or plant antibiotic (Bishayee, 2009; Harikumar, Aggarwal, 2008). It is synthesized by certain species and genera of higher plants via shikimic acid or acetic metabolic pathways (phenylalanine being the RSV's precursor and stilbene synthase the enzyme that catalyses the reaction), triggered by exogenous plant stress conditions, such as microbial/fungal infection, injury, ultraviolet (UV) irradiation and exposure to heavy metal ions, serving as a first line of chemical defense (Das et al., 2008; Hung et al., 2008; López-Nicolás, García-Carmona, 2008; Lu et al., 2009; Lucas-Abellán et al., 2011; Murias et al., 2005; Santos, Veiga, Ribeiro, 2011; Smoliga, Baur, Hausenblas, 2011; Snyder, Gollner, Chiriac, 2011).

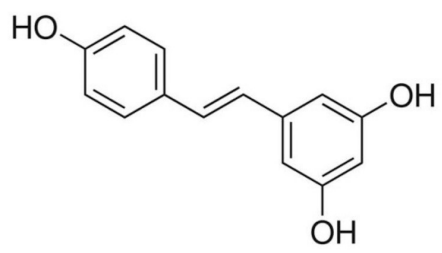

FIGURE 1 - Resveratrol chemical structure.

First isolated from the roots of white hellebore (Veratrum glandiflorum), the extract of which contains trans-RSV of a purity range of $10 \%$ to $99 \%$, RSV is mainly found in daily foods, such as grapes (fresh grape skin contains about $50-100 \mu \mathrm{g}$ of RSV), red wine (1.5-3 mg/L of RSV), cranberries, peanuts, and was recently discovered in chocolate, cocoa and tomato (Amri et al., 2012; Counet, Callemien, Collin, 2006; Harikumar, Aggarwal, 2008; Huang, Zhu, 2011; Ragab et al., 2006; Syed, Mukhtar, 2011). Several epidemiologic studies have reported RSV, present in red wine, as responsible, at least in part, for the 'French paradox', the apparent ability of moderate consumption of red wine to reduce cardiovascular disease, reflected by the low incidence of coronary heart disease mortality in France in relation to other countries, despite its culture of a fat-rich diet (Bishayee, 2009; Lucas-Abellán et al., 2007; Smoliga, Baur, Hausenblash, 2011).

The following applications reported for this stilbene are, in great part, underestimated, as this molecule is subject to extensive pre-systemic metabolism through first-pass glucuronidation and sulphate conjugation (phase II conjugation reactions), both in the small intestine and the liver (Figure 2). This is often assigned as the main cause of the trace amounts of it found in human plasma (less than $5 \mathrm{ng} / \mathrm{mL}$ ), and consequently responsible for its restricted oral bioavailability (Amri et al., 2012; Das et al., 2008; Huang, Zhu, 2011; Hung et al., 2008; Muzzio et al., 2012; Rotches-Ribalta et al., 2012; Santos, Veiga, Ribeiro, 2011).

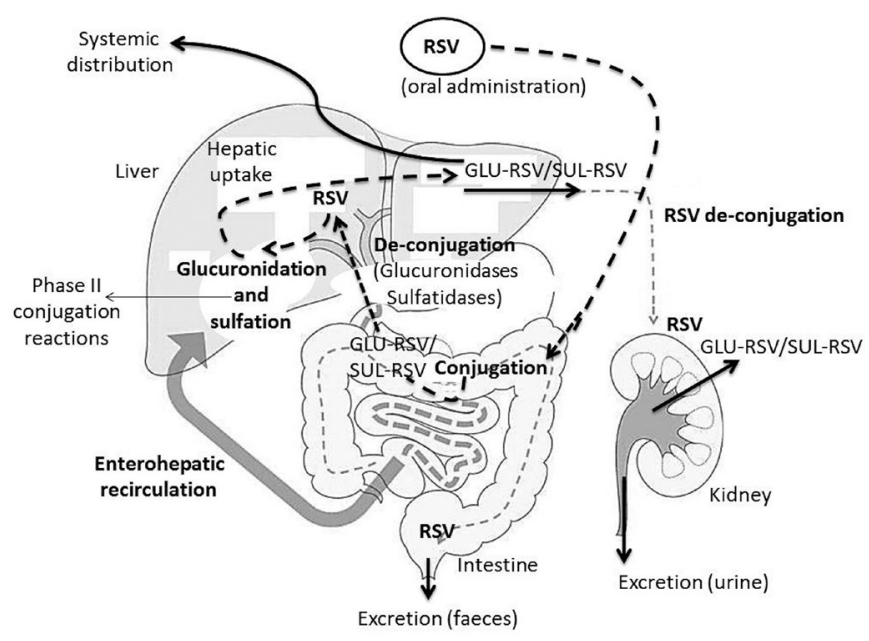

FIGURE 2 - Resveratrol simplified metabolism (RSV Resveratrol; GLU-RSV - Resveratrol glucuronide form; SUL-RSV - Resveratrol sulphated form) (adapted from (Halilbasic, Claudel, Trauner, 2013).

\section{THERAPEUTICAL APPLICATIONS OF RESVE- RATROL}

RSV has received considerable attention, as several in vitro and in vivo studies report its variable biological activities, and its potential as a disease-preventing agent, since this compound shows promising properties in the prevention and treatment of a wide variety of chronic ailments, including cardiovascular, pulmonary and neurodegenerative diseases, obesity, diabetes, skin disorders, arthritis, cancer and even the aging process (Harikumar, Aggarwal, 2008; Murias et al., 2005; Muzzio et al., 2012; Santos, Veiga, Ribeiro, 2011; Smoliga, Baur, Hausenblash, 2011). These studies have demonstrated that RSV has antioxidant properties at low oral doses (10 $\mu \mathrm{M})$, acting as a potent radical scavenger, as it modulates lipid metabolism, protects low density lipoproteins (LDL) 
against oxidative and free radical damage, and inhibits platelet activation and aggregation. It also demonstrates strong chemopreventive and cytostatic effects at higher concentrations $(100 \mu \mathrm{M})$, blocking the carcinogenesis principle stages of initiation (changes at the genetic level), followed by promotion and progression, that finally culminate in malignancy (Amri et al., 2012; Bhat, Pezzuto, 2002; Bishayee, 2009; Caddeo et al., 2008; Kundu, Surh, 2008; Murias et al., 2005; Santos, Veiga, Ribeiro, 2011).

Other pharmacological activities of RSV include being anti-inflammatory, antimicrobial against dermatophytes and herpes simplex, analgesic, and anti-aging, the last only seen, at the moment, in lower organisms, such as yeast, mice and fish (Amri et al., 2012; Cottart et al., 2010; Harikumar, Aggarwal, 2008; Smoliga, Baur, Hausenblash, 2011). Concerning these properties, RSV has been subject to several clinical trials, and much of the published data on RSV in humans is summarized in Table I.

\section{Resveratrol mechanisms of action}

In terms of the mechanisms of action, RSV may display dual proceedings (cell protection or cell apoptosis) depending on the cellular conditions, concentration used, cytosolic redox status and duration of contact (Caddeo et al., 2008; Huang, Zhu, 2011; Santos, Veiga, Ribeiro, 2011). The chemical structure of RSV allows it to interact with several receptors, kinases and other enzymes, which may lead to the prevention of many disease conditions that are the consequence of cell damage or death, triggered by severe oxidative stress, including Alzheimer's, Parkinson's, cancers, heart disease, multiple sclerosis, and others (Huang, Zhu, 2011; Santos, Veiga, Ribeiro, 2011; Smoliga, Baur, Hausenblash, 2011).

\section{Antioxidant activity}

Similar to most polyphenols, RSV displays intrinsic antioxidant activity, acting as a potent radical scavenger, inhibiting hydrogen peroxide- or lipid hydroperoxidedependent lipid peroxidation of cellular membrane lipids, thus protecting the systemic erythrocytes. Additionally, RSV also supresses the activity of the lipopolysaccharide-inducible form of nitric oxide synthase by the vascular endothelium, demonstrated by a decrease in nitric oxide production, also inhibiting the oxidation of the LDL through the in vivo chelation of copper, therefore suggesting a possible role in the prevention of atherosclerosis and coronary heart disease (Amri et al., 2012; Bhat, Pezzuto, 2002; Harikumar, Aggarwal, 2008; Kundu, Surh, 2008; Smoliga, Baur, Hausenblash, 2011). It is worth noting that RSV's antioxidant effects are most likely mediated through its ability to induce antioxidant enzymes, such as catalase, superoxide dismutase and glutathione peroxidase hemoxygenase (Hsieh, $\mathrm{Wu}, 2010$ ).

TABLE I - Human clinical trials performed using RSV

\begin{tabular}{|c|c|c|c|}
\hline Aim of Study & Dose & Volunteers & Results \\
\hline Safety and dose-finding & $0-5 \mathrm{~g}$ (oral) & 10 & $\begin{array}{l}\text { Safe up to } 5 \mathrm{~g} \text {; highest blood levels } 1.5 \mathrm{~h} \text { after } \\
\text { intake; rapid urinary excretion (Kim et al., 2006) }\end{array}$ \\
\hline $\begin{array}{l}\text { Safety, pharmacokinetics, } \\
\text { dosing with quercetin/alcohol }\end{array}$ & 2000 mg twice/daily & 8 & $\begin{array}{l}\text { RSV was well tolerated, but 6/8 volunteers } \\
\text { reported diarrhoea (Kim and Snyder, 2010) }\end{array}$ \\
\hline $\begin{array}{l}\text { Effects of food on RSV } \\
\text { absorption }\end{array}$ & $400 \mathrm{mg}$ & 24 & $\begin{array}{l}\text { The extent of absorption was not affected by food, } \\
\text { but the rate of absorption was delayed with food } \\
\text { (Ansari et al., 2011) }\end{array}$ \\
\hline $\begin{array}{l}\text { Pharmacokinetics of multiple } \\
\text { doses }\end{array}$ & $0-150 \mathrm{mg}, 6 x /$ day & 40 & $\begin{array}{l}\text { Repeated dosing well tolerated; higher } \\
\text { bioavailability after morning administration } \\
\text { (Mehnert, Mäder, 2001) }\end{array}$ \\
\hline Bioavailability from red wine & $\begin{array}{c}246 \mu \mathrm{g}-1.92 \mathrm{mg} \\
\text { (three different wines) }\end{array}$ & 25 & $\begin{array}{l}\text { Trace amounts found in some subjects } 30 \text { minutes } \\
\text { after ingestion (Atanacković, Gojković-Bukarica } \\
\text { and Cvejić, 2012) }\end{array}$ \\
\hline Glycemic control & $250 \mathrm{mg}$ & 72 & $\begin{array}{l}\text { Improvement of glycemic control in type } 2 \\
\text { diabetes mellitus (Bhatt, Thomas, Nanjan, 2012) }\end{array}$ \\
\hline Effect in healthy smokers & $500 \mathrm{mg}$ & 50 & $\begin{array}{l}\text { Significant reduction in C-reactive protein and } \\
\text { triglyceride concentrations (Bo et al., 2013) }\end{array}$ \\
\hline $\begin{array}{l}\text { Effect in non-alcoholic fatty } \\
\text { liver disease }\end{array}$ & $2150 \mathrm{mg}$ & 60 & $\begin{array}{l}\text { Significant improvement of insulin resistance, } \\
\text { glucose and lipid metabolism (Chen et al., 2015) }\end{array}$ \\
\hline
\end{tabular}




\section{Anti-aging capacity}

Another interesting application of RSV is related to its anti-aging capacity, as RSV is responsible for the enhancement on the genetic expression of the Silent Information Regulator2, a gene associated with longevity, whose homolog in mammals is known as SIRT1, being responsible for the codification of the sirtuin enzymes $\left(\mathrm{NAD}^{+}\right.$-dependent histone deacetylases, involved in gene silencing processes, blockade of apoptosis and promotion of cell survival), mimicking the known lifespan-extending effects of caloric restriction or partial food deprivation on lipid metabolism, gluconeogenesis and liver glycolysis monitoring, as caloric restriction was found to reduce inflammation, atherosclerosis, effects of aging and insulin resistance (Caddeo et al., 2008; Harikumar, Aggarwal, 2008; Paulo et al., 2011; Pezzuto, 2011; Pirola, Fröjdö, 2008; Rotches-Ribalta et al., 2012; Shukla, Singh, 2011).

Staying with the interference in the aging process, several other studies report RSV's induction of the 5'AMPactivated protein kinase, important in fat metabolism in the liver, as it enhances fatty acid oxidation and downregulates the activity of the HMG-CoA reductase, the rate-limiting step in cholesterol synthesis (Collado et al., 2013). Furthermore, RSV plays a role as a phytoestrogen, based on its structural similarity to the synthetic oestrogen diethylstilbestrol, being able to bind to estrogenic receptors, in an agonist/antagonist manner, and regulate the transcription of oestrogen-responsive genes, highlighting its potential applications in the prevention and treatment of age-related diseases (Bhat, Pezzuto, 2002; Huang, Zhu, 2011; Ovesna et al., 2006; Smoliga, Baur, Hausenblash, 2011).

\section{Anti-inflammatory capacity}

As an anti-inflammatory agent, RSV has been reported to decrease oxidative stress and attenuate inflammation. The development of oxidative stress is involved with an excessive accumulation of reactive oxygen species (ROS), normal by-products of cellular physiology, which are continuously removed by enzymatic and non-enzymatic antioxidants that scavenge the radicals. Therefore, as a potent antioxidant and anti-inflammatory agent, RSV may attenuate these species, and prevent, treat or even cure strong acute inflammatory ailments, such as atherosclerosis, diabetes, chronic obstructive pulmonary disease and several types of cancer (prostate, breast, colon, brain, pancreas, skin, lung, liver, ovary and bladder), interfering with the targeting members of the apoptotic family and signalling pathways that include a number of inflammatory biomarkers (Bhat, Pezzuto, 2002; Caddeo et al., 2008; Harikumar, Aggarwal, 2008; Kundu, Surh, 2008;
Shukla, Singh, 2011; Smoliga, Baur, Hausenblash, 2011). Issuree et al. (2009) reported the anti-inflammatory effect of RSV by pre-treating human and mice neutrophils with different RSV concentrations, to which a pro-inflammatory agent had previously been administered. They concluded that the pre-treatment of the aforementioned cells with RSV significantly blocked oxidative burst, leukocyte migration, degranulation, and inflammatory cytokine production. Additionally, the authors reported that the anti-inflammatory action of RSV was a function of the inhibition of the sphingosine kinase activity, its membrane location, and sphingosine kinase1-mediated calcium ion release. This also provides evidence that the sphingosine kinase inhibitory effect of RSV has an upstream role in the nuclear factor kappa B (NF- $k$ B) pathway of inflammation, inhibiting its signalling which, in turn, decreases the transcription of DNA, and down-regulates pro-inflammatory cytokine expression, such as interleukin-1 (IL-1, IL-6 and IL-8) and tumour necrosis factor- $\alpha$ (TNF- $\alpha$ ) (Harikumar, Aggarwal, 2008; Issuree et al., 2009; Kundu, Surh, 2008; Smoliga, Baur, Hausenblash, 2011).

\section{Vascular support capacity}

In terms of vascular support, RSV is showed to inhibit C-reactive protein, a non-specific inflammatory marker of cardiac risk, which can induce vascular endothelial dysfunction and promote atherosclerosis when increased (Harikumar, Aggarwal, 2008; Smoliga, Baur, Hausenblash, 2011). Furthermore, RSV was shown to induce the relaxation of mesenteric resistance arteries in both lean and dietary-obese rats, whose induction may either be endothelium dependent or independent. This vasorelaxant effect of RSV may contribute to reducing blood pressure and, by lowering the myocardial work, it may also contribute to the beneficial cardiovascular effects of RSV in several disorders, such as hypercholesterolemia, hypertension, type 2 diabetes and obesity, where endothelial function is attenuated (Harikumar, Aggarwal, 2008).

\section{Immune-regulation capacity}

Considering the immune-regulation, RSV exerts a dose-related regulatory effect on human immune cell functions in vitro. It was found that RSV modulates the natural killer effector cells, in a concentration-related manner, and the differentiation of both cytokine-producing $\mathrm{CD}^{+}$and $\mathrm{CD}^{+}{ }^{+} \mathrm{T}$ cells, the last ones being significantly more sensitive to the effect of this compound. Additionally, lower concentrations of RSV were found to induce a significant enhancement in the frequency of $\mathrm{CD} 4^{+}$and 
$\mathrm{CD}^{+} \mathrm{T}$ cells producing three types of cytokines (type 0 , 1 and 2 cells; type 1 being involved in the secretion of IL2 , INF- $\gamma$ and lymphotoxin, type 2 cells being involved in the production of IL-4, IL-5, IL-10 and IL-13, and type 0 cells being able to produce both type 1 and 2 cytokines). Higher concentrations of RSV revealed suppression features in lipopolysaccharide-activated macrophages, further suggesting its action as an immuno-modulating agent (Bishayee, 2009). Additionally, CD28, CD80 and CD86 immune cells are also significantly down-regulated (Harikumar, Aggarwal, 2008).

\section{Antineoplastic activity}

In addition to these properties, RSV has also demonstrated an antineoplastic activity. RSV has attracted scientific interest since 1997, as it was firstly demonstrated, in a two-stage mouse skin model, that it prevented carcinogenesis in mice. It has been shown that this compound is indeed able to inhibit the development of pre-neoplastic lesions in female mice mammary glands in culture (Jang et al., 1999), tumorigenesis in a female mouse skin tumour model (Jang et al., 1999), and the proliferation of a wide moiety of tumour cell lines (Bhat, Pezzuto, 2002; Bishayee, 2009; Kundu, Surh, 2008; Smoliga, Baur, Hausenblash, 2011). Extensive study over the past decade has shown both the chemopreventive and chemotherapeutic potential of RSV, in particular, the chemoprevention of skin cancer discussed in this review.

In particular, at low doses, RSV was found to up-regulate the CD95-CD95L system for the control of apoptosis, triggering CD95 signalling-dependent apoptosis in human promyelocytic leukaemia and breast cancer cells (Harikumar, Aggarwal, 2008; Kundu, Surh, 2008; Ovesna et al., 2006; Shukla, Singh, 2011), arresting/delaying the cell division cycle at phase $\mathrm{S} / \mathrm{G} 2$ transition, and inducing the expression of both the tumour suppressor gene p53 and also the cyclin-dependent kinase inhibitor gene $\mathrm{p} 21$, an androgen-induced gene (Bhat, Pezzuto, 2002; Bishayee, 2009; Harikumar, Aggarwal, 2008; Huang, Zhu, 2011; Kundu, Surh, 2008; Ovesna et al., 2006; Pezzuto, 2011). In breast cancer cells, RSV induced cell death by inhibiting fatty acid synthase and human epidermal growth factor receptor 2 genes (Khan et al., 2014). Moreover, recent data confirm that RSV blocks the TNF- $\alpha$-induced activation of $\mathrm{NF}-k \mathrm{~B}$ (an inducible transcription factor strongly linked to the inflammatory and immune responses, and associated with oncogenesis in certain models of cancer), possibly via inhibition of ROS and lipid peroxidation, as well as by reducing phosphorylation and nuclear translocation of the p56 subunit of NF- $k \mathrm{~B}$, where it regulates the expression of genes involved in inflammation, cell proliferation, apoptosis, tumorigenesis and metastasis (Shukla, Singh, 2011). At the same time, RSV showed an ability to inhibit UV-B-induced activation of NF- $k$ B in normal human epidermal keratinocytes (Kundu, Surh, 2008).

RSV may also bind directly to cycloxigenase-2 (COX-2), triggered by cytokines and endotoxins, suppressing its activity. As COX-2 is responsible for the production of inflammatory prostaglandins (PGs), this enzyme is a potential target for cancer prevention, as it is abundantly expressed in a wide range of cancers, thus down-regulating PGs biosynthesis (Amri et al., 2012; Bhat, Pezzuto, 2002; Kim et al., 2011; Kundu, Surh, 2008). Another important fact about RSV is related to its ability to inhibit some cytochrome $\mathrm{P} 450\left(\mathrm{CYP}_{450}\right)$ isozymes, which displays an important role in the metabolism of xenobiotics, converting these substances into polar intermediates, which are subsequently eliminated via conjugation reactions catalysed by phase II enzymes. The P450s, capable of metabolizing a wide variety of carcinogens, are overexpressed in a multitude of human tumours, including breast, colon and lung (Bhat, Pezzuto, 2002; Kundu, Surh, 2008).

\section{- Resveratrol and skin cancer}

Skin cancer is the most common and prevalent of all newly diagnosed cancers in the world, and is related to the type of cells that become malignant, such as melanoma, basal and squamous cell carcinomas (non-melanoma) (Green, Khavari, 2004; Ndiaye et al., 2011). Fortunately, most of these cancers are slow-growing, easy to recognize, and relatively easy to treat when diagnosed early (Teskač, Kristl, 2010).

As mentioned above, RSV exerts chemopreventive effects in skin, firstly reported by Jang et al. (1999), who conducted the first animal study, reporting its chemopreventive effects through a two-stage mouse skin cancer model. In this study, the topical application of RSV significantly decreased 7,12-dimethylbenz $(\alpha)$ anthracene (DMBA)-initiated, and 12-O-tetradecanoylphorbol-13acetate (TPA)-promoted skin tumours in female CD-1 mice (Huang, Zhu, 2011; Jang et al., 1999), and confirmed RSV's potential as an antineoplastic agent, especially highlighted at higher RSV concentrations $(25 \mu \mathrm{mol})$, evidencing tumour promotion inhibition. Subsequent studies have demonstrated that pre-treating mouse skin with RSV significantly suppresses several TPA-induced effects, including increased expressions of cyclooxygenase (COX-1, COX-2), transforming the growth factor- $\beta 1$ (TGF- $\beta 1$ ) and the TNF- $\alpha$ (Hsieh, Wu, 2010; Kim et al., 2011). In this context, Afaq, Adhami and Ahmad (2003) found that RSV can enhance oedema and inflammation 
triggered by short-term UV-B exposure in the skin of SKH-1 hairless mice, apparently due to COX and lipid peroxidation inhibition and, consequently, topical RSV inhibited the skin hyperplasia induced by the radiation used in the mouse model. Together, these collective melanoma data suggest that RSV effects on melanoma depend on dose, route of administration and the specific model studied (Afaq, Adhami, Ahmad, 2003; Jang et al., 1999; Kundu, Surh, 2008; Reagan-Shaw et al., 2004).

Recently, Kim et al. (2011) reported that oral administration of RSV to highly tumour-susceptible $\mathrm{p} 53^{+/-}$ SKH-1 mice delayed UV-induced skin tumorigenesis significantly, and reduced the malignant conversion of benign papillomas to squamous cell carcinoma (SCC) cells, further reducing the tumour growth factor $\beta 2$ (TGF- 32 ), also predominantly overexpressed in UV-Binduced SCCs. Previously, they have also found that oral administration of RSV supressed the growth of A431 human epidermoid SCC cells lacking the functional p53 tumour suppressor gene (Kim et al., 2006; Kim et al., 2011). Beyond these studies, researchers at Columbia's Department of Dermatology are studying RSV as a possible preventive agent for basal cell carcinoma and SCC treatments. In one experiment, (Kim, Snyder, 2010) fed mice with regular doses of an oral solution of RSV, and exposed them to UV-B light. They found a 70\% reduction in non-melanoma skin tumours in the treated mice, in comparison to a control group.

As early treatment is essential to reduce disease mortality and morbidity, potent topical agents for skinlocalized cancers and their precursors are of special interest, facing the challenges of developing effective specific agents targeted at molecules of interest, and transdermal delivery of these therapeutics across the skin permeable barrier (Green, Khavari, 2004). Although increasingly being recognized as a potential chemotherapeutic agent, the clinical application of RSV is hindered by its poor water solubility, fast degradation and lack of human clinical trials. In this context, the design and characterization of novel vehicles is justified for solubilization, stabilization and controlled delivery of this compound, in order to obtain an enhanced molecule that can undergo human trials and, therefore, be placed in the medicinal arsenal.

Figure 3 highlights several changes which arise from skin exposure to UV-radiation, resulting in skin cancer, and RSV's ability to inhibit/decrease some of these transformations, in order to avoid skin cancer development (Kostyuk et al., 2013).

- Anti-diabetic activity

There is much speculation on RSV's potential

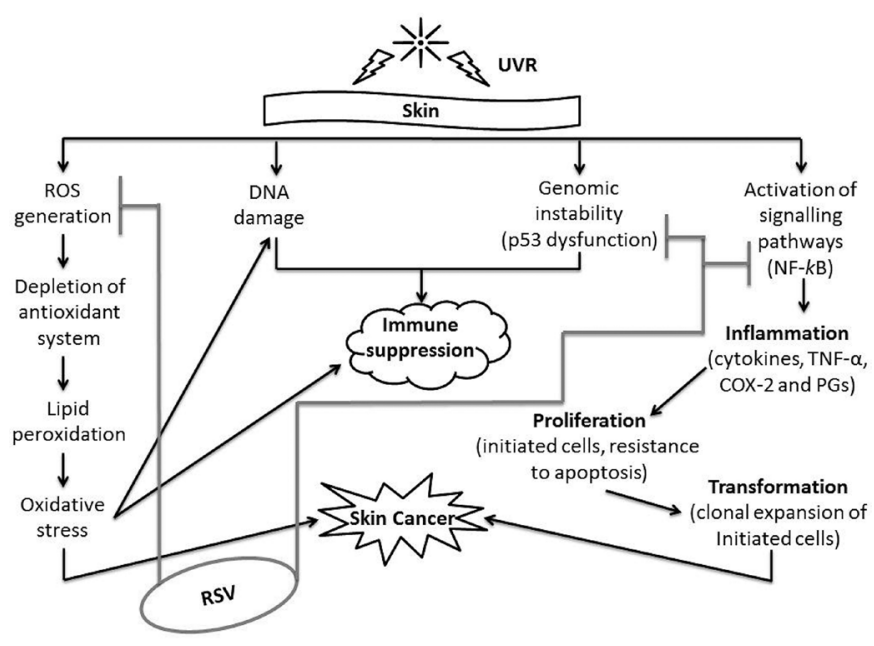

FIGURE 3 - Skin cancer development and RSV ability to inhibit some skin-derived-UVR-transformations (UVR - UV radiation; RSV - Resveratrol; PGs - Prostaglandins) (adapted from Afaq, 2011).

anti-diabetic activity in humans, as studies developed in rodent models of diet-induced obesity showed that RSV can improve insulin sensitivity and decrease body weight (Lagouge et al., 2006; Smoliga, Baur, Hausenblash, 2011). Moreover, Orhan et al. (2006) found that the aqueous extract obtained from Vitis vinifera leaves exhibits significant antihyperglycaemic and antioxidant activity, equipotent with the reference hypoglycaemic agent tolbutamide, when evaluated in diabetic rats. Numerous mechanisms have been proposed to account for the insulinsensitizing effects of RSV, including the aforementioned anti-inflammatory effects, stimulation of glucose uptake by hepatocytes, adipocytes, and skeletal muscle and hepatic glycogenesis, SIRT1-dependent suppression of protein-tyrosine phosphatase $1 \mathrm{~B}$ (PTP1B, phosphatase which acts on the insulin receptor) (Harikumar, Aggarwal, 2008; Kundu, Surh, 2008; Peng et al., 2010; Shukla, Singh, 2011), and prevention of ectopic lipid accumulation in muscle and liver by increased mitochondrial content in diabetic mice (Baur et al., 2006; Harikumar, Aggarwal, 2008; Lagouge et al., 2006; Smoliga, Baur, Hausenblash, 2011).

Figure 4 summarizes the principle and potential activities reported for RSV, as well as its mechanisms of action.

\section{Therapeutic systems for resveratrol delivery}

The design of novel therapeutic systems implies an adequate understanding of the molecule physicochemical properties. In the case of RSV, this compound exhibits 


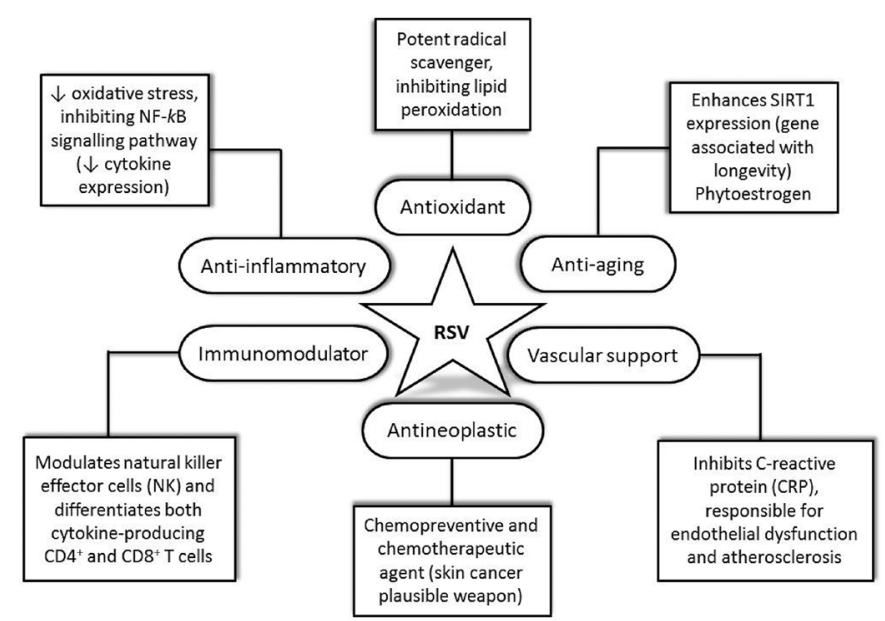

FIGURE 4 - Diagram of RSV potential applications.

low water solubility and high solution instability. Over the past decades, researchers have aimed at developing new strategies to obtain new formulations, which protect and stabilize RSV (Amri et al., 2012; Ansari et al., 2011; Augustin, Sanguansri, Lockett, 2013; Ndiaye et al., 2011). Furthermore, Santos, Veiga and Ribeiro (2011) reported that RSV should be delivered to its site of action to attain an ideal response, in order to intensify its therapeutic effects and reduce its side effects.

However, the existence of several colloidal carrier systems faces us with the question of which of them might be suitable for the desired purpose. Bearing this in mind, there are some aspects which need to be considered, including drug loading capacity, possibility of drug targeting, in vivo fate of the carrier (interaction with the biological surrounding, degradation rate and accumulation in organs), acute and chronic toxicity, scaling up of production, physicochemical storage stability, and overall costs. Taking into account all these aspects, particularly RSV solubility and stability, Table 2 summarizes the principle characteristics of new therapeutic systems for RSV delivery.

\section{Micellar systems}

Micellar solutions of bile acids allow the solubilization of poorly soluble organic substances and can improve their resorption, as these micelles are composed of bile acids, which represent bi-planar biological surfactants, with two functionally different molecular surfaces: a hydrophobic convex surface of steroid core, and a hydrophilic concave surface, representing amphiphilic molecules (Atanacković et al., 2009; Atanacković, Gojković-Bukarica, Cvejić, 2012). Furthermore, these compounds have been studied as permeability enhancers of biological membranes, such as the skin barrier, as above their critical micellar concentration (CMC), they can associate with cell membrane phospholipids and cause interruption of membrane integrity. Atanacković et al. (2009) investigated the solubilization of RSV in micellar solutions of bile acids containing keto groups in their structures. They concluded that keto derivatives of bile acids, such as 3,7,12-triketocholic acid, had the highest affinity for RSV solubilization, and also displayed the smallest membranolytic potential, with a high CMC value of $2.00 \mathrm{mM}$ (Atanacković et al., 2009; Atanacković, Gojkovic-Bukarica, Cvejic, 2012).

\section{Cyclodextrins}

Cyclodextrins (CDs), are naturally occurring cyclic oligosaccharides that represent starch derivatives composed of $(\alpha-1,4)$-linked $\alpha$-D-glucopyranose residues, exhibiting a truncated cone or torus structure with a hydrophobic central cavity and hydrophilic rims of the surrounding walls, which are known to form inclusion complexes with many guest molecules (Delmas et al., 2011; Lucas-Abellán et al., 2007; Vyas, Saraf, 2008). These systems may be differentiated into two groups: naturals $(\alpha, \beta$ and $\gamma$-CDs) and chemically modified, being sulfobutyl ether- $\beta$-CDs and hydroxypropyl (HP)- $\beta$-CDs the semi-synthetic derivatives of particular pharmaceutical interest (Amri et al., 2012; López-Nicolás, GarcíaCarmona, 2008; Vyas, Saraf, 2008). In terms of functions, CDs act as dosage-controlled reservoirs, protecting RSV against rapid oxidation by free radicals, lipoxygenase and other oxidative enzymes, further increasing its antioxidant activity through the entrapment of the drug in the internal cavity (Amri et al., 2012; López-Nicolás, RodriguezBonilla, Garcia-Carmona, 2009; Lucas-Abellán et al., 2007; Vyas, Saraf, 2008).

Recently, Santos, Veiga and Ribeiro (2011) reported a study with RSV, in which the increase in the RSV antioxidant activity by complexing RSV with HP- $\beta-C D$ was confirmed, and reached its maximum when the totality of the molecule was complexed. Beyond displaying a larger inclusion ability, due to the enlargement of the cavity in relation to intramolecular hydrogen bond network damage induced by hydroxypropyl (HP) substitutions, the complexation with the HP- $\beta$-CD provided extra alterations on RSV, especially on its dissolution capacity, stability and slowing of its rapid metabolism and elimination, as this $\beta$-CD derivative exerts high cellular recognition and high aqueous solubility (Amri et al., 2012; Das et al., 2008; Lu et al., 2009; Santos, Veiga, Ribeiro, 2011).

Previously, Ansari et al. (2011) focused on the preparation, characterization, cytotoxicity and permeation of a novel formulation of RSV-loaded cyclodextrin- 
TABLE II - New therapeutic systems for RSV delivery

\begin{tabular}{|c|c|c|c|}
\hline \multirow{2}{*}{ Delivery System } & \multicolumn{3}{|c|}{ Effect on RSV properties } \\
\hline & Solubility & Stability & Release/bioavailability \\
\hline Micellar Solutions & $\begin{array}{l}\uparrow \text { RSV solubilization by } \\
3,7,12 \text {-triketocholic acid } \\
\text { (Atanacković et al., 2009; } \\
\text { Atanacković, Gojkovic- } \\
\text { Bukarica and Cvejic, 2012) }\end{array}$ & NA & NA \\
\hline $\begin{array}{l}\text { Nanoemulsions/ } \\
\text { Microemulsions }\end{array}$ & $\begin{array}{c}\text { Optimized microemulsion } \\
\text { improved RSV solubility } \\
\text { (Bolko, Zvonar, Gasperlin, } \\
\text { 2014) } \\
\end{array}$ & $\begin{array}{l}\text { Improved physical stability } \\
\text { (Singh, Pai, 2014; } \\
\text { Sessa et al., 2014) }\end{array}$ & $\begin{array}{l}\text { Improved oral bioavailability } \\
\text { (Singh, Pai, 2014; } \\
\text { Sessa } \text { et al. }, 2014 \text { ) }\end{array}$ \\
\hline Cyclodextrins & $\begin{array}{c}\uparrow \text { solubility of resulting } \\
\text { complexes (Narayanan } \text { et al., } \\
\text { 2009) } \\
\text { Solubility of RSV-CD complex } \\
\text { at least > } 100 \text { times (López- } \\
\text { Nicolás, Rodriguez-Bonilla, } \\
\text { Garcia-Carmona, 2009) }\end{array}$ & $\begin{array}{c}\text { Stabilization at pH 5.5-8.5 } \\
\uparrow \text { HP- } \beta \text {-CD- } t \text {-RSV complex } \\
\text { stability (Amri et al., 2012; } \\
\text { López-Nicolás, } \\
\text { Rodriguez-Bonilla, } \\
\text { Garcia-Carmona, 2009) }\end{array}$ & $\begin{array}{c}\text { Controlled release } \\
\text { (López-Nicolás, Rodriguez- } \\
\text { Bonilla, Garcia-Carmona, } \\
\text { 2009) }\end{array}$ \\
\hline
\end{tabular}

Partition of RSV into the SLN sphere, physical stability (stable

Poloxamer 188 enhances Solid Lipid Nanoparticles RSV solubility (Teskač, Kristl, 2010) for at least four weeks) (Teskač,

Kristl, 2010); Improved physical

Sustained release (Teskač, Kristl, 2010)

stability for two months

(Neves et al., 2013)

\begin{tabular}{lccc}
\hline Polymeric Nanoparticles & $\begin{array}{c}\text { Carboxymethyl chitosan } \\
\text { nanoparticles improve } \\
\text { solubility (Zu et al., 2014) }\end{array}$ & NA & $\begin{array}{c}\text { Controlled release and better } \\
\text { bioavailability (Zu } \text { et al., 2014; } \\
\text { Sanna } \text { et al., 2013); Improved } \\
\text { bioavailability and liver } \\
\text { targeting (Bu } \text { et al., 2013) }\end{array}$ \\
\hline Liposomes & $\begin{array}{c}\text { Optimized formulation } \\
\text { improved solubility } \\
\text { (Basavaraj, Betageri, 2014) }\end{array}$ & $\begin{array}{c}\text { Protection from light and other } \\
\text { degradation processes } \\
\text { (Delmas } \text { et al., 2011) }\end{array}$ & $\begin{array}{c}\text { Slow and sustained release } \\
\text { (Delmas et al., 2011); Improved } \\
\text { bioavailability (Basavaraj, } \\
\text { Betageri, 2014) }\end{array}$ \\
\hline Chitosan Microspheres & NA & $\begin{array}{c}\uparrow \text { irradiation resistance } \\
\uparrow \text { thermal stability } \\
\text { (Peng } \text { et al., 2010) }\end{array}$ & $\begin{array}{c}\text { First burst release } \\
\text { Second slow release } \\
\text { (Peng } \text { et al., 2010) }\end{array}$ \\
\hline DPPC-HA Microspheres & NA & NA & $\begin{array}{c}\text { Slow release } \\
\text { (Eroğlu et al., 2015) }\end{array}$ \\
\hline
\end{tabular}

NA: Not Available, CD: Cyclodextrin, RSV: Resveratrol, SLN: Solid Lipid Nanoparticle, DPPC: Dipalmitoylphosphatidylcholine, HA: Hyaluronic Acid

based nanosponges (NS). These NS-CDs represent hyper-cross-linked cyclodextrins, prepared by dissolving nanostructured $\beta$-CDs in dimethylformamide, using carbonyldiimidazole as a cross-linker (Amri et al., 2012; Ansari et al., 2011). These authors concluded that RSVloaded-CD-NS complexes exerted increased solubility and wettability, owning a loading efficiency between $30 \%$ and $40 \%$. In addition, RSV-loaded NS have an appropriated particle size (ranging from 400-500nm), displaying a better photostability in relation to the pure drug. Furthermore, the permeation of RSV through the pig skin ex vivo study revealed that the previous formulation promoted a rapid inhibition of HCPC-I carcinogenic cell proliferation, exerting a significantly better cytotoxicity against these neoplastic cells and consequently representing a viable system for topical delivery (Amri et al., 2012; Ansari 
et al., 2011). The previous data demonstrated that the complexation of RSV with CDs proved to be a solution to overcome the limited aqueous solubility of RSV, and facilitating its dissolution rate in aqueous media, which results in an improvement of RSV's bioavailability.

\section{Polymeric microspheres}

Monodisperse polymeric microspheres represent an efficient system for extremely photosensitive molecules, providing stabilization and preservation of these molecules (Amri et al., 2012). Nam et al. (2005) prepared these systems by seeded polymerization in the presence of porogen, giving raise to particles of about $5 \mu \mathrm{m}$ in diameter containing cyano-functional groups, which contributed to the stabilization of RSV in the porous particles (as the micron size range of the porous particles efficiently scattered the sunlight and heat, responsible for the inhibition of RSV antioxidant activity), preventing its immediate release. Authors reported that the RSV bioactivity was sustained for five weeks, preserved at over 93\% in ethanolic media, demonstrating a strategy for RSV stabilization in solution.

Shi et al. (2008) evaluated the preparation of yeast-encapsulated RSV using Saccharomyces cerevisiae (baker's yeast) as the encapsulating wall material. The yeast-encapsulated RSV revealed slower photodecomposition and stronger free radical scavenging activity than raw RSV, further disclosing the higher stability of encapsulated RSV under wet and illumination stresses. Finally, the sustained release pattern suggested that RSV's weak bioavailability, in great part due to rapid metabolism and elimination, could be partially supplemented by this successful yeast cell-based microencapsulation technique for stabilizing solid RSV, promoting an extension of shelf-life (when stored at $4{ }^{\circ} \mathrm{C}$ and room temperature), protection against oxidation, and a slow-controlled release of the drug.

Chitosan, a natural polysaccharide derived from chitin by alkaline deacetylation, displays good atoxic properties, biocompatibility and mechanical biofilmforming ability, being suitable as a delivery system of active agents in the format of microspheres, further increasing the timeframe and controlled release property of such actives when crosslinked. A recent study, conducted by Peng et al. (2010), demonstrated that RSVloaded chitosan microspheres, cross-linked by vanillin (GRAS substance), obtained from the tropical Vanilla planifolia, displayed high stability regarding light and heat. Furthermore, three different mechanisms were also proposed for RSV release from the chitosan spheres, including release from the surface of particles, diffusion through the swollen rubbery matrix, and release due to polymer erosion. In relation to the release pattern, it was divided in two phases, the first characterized by an initial rapid release of RSV (burst release), and the later characterized by a slow release (controlled release) of the drug. Additionally, the burst release rapidly allowed the achievement of the effective RSV concentration in plasma, whereas the controlled release maintained the previous for a long time, suggesting that RSV weak bioavailability could be enhanced by an encapsulation method, prolonging its biological half-life in vivo.

\section{Liposomes}

Liposomes represent small concentric vesicles, in which an aqueous volume core is entirely enclosed by a membranous amphiphilic phospholipid bilayer (in most cases, phosphatidylcholine), similar to the biological membranes (Mehnert, Mäder, 2001; Vyas, Saraf, 2008). These carriers entrap hydrophilic drugs in the inner aqueous phase, and hydrophobic ones within the lipid bilayers, protecting them until they reach their destination (Delmas et al., 2011; Mehnert, Mäder, 2001; Vyas, Saraf, 2008). RSV localizes preferentially at the liposome surface, where it remains biologically active in the transconformation, protecting RSV from the light and other degradative processes. The liposomal bilayers store RSV, avoiding overloading of the cells' membranes by the slow and sustained release of RSV to the biological domains, also avoiding cytotoxicity at high concentrations (even at $100 \mu \mathrm{M}$ ), further promoting stimulation of the cell-defence system and RSV long-term stability and biological activity against UV-B-induced oxidative damage (Amri et al., 2012; Delmas et al., 2011; Santos, Veiga, Ribeiro, 2011). In addition, these carriers allow cytoplasmic delivery, as its membranes fuse with cell membranes, or liposomes are endocytosed by the cells and then release their content into the cytoplasm (Delmas et al., 2011).

Another study, conducted by Narayanan et al. (2009), reported the development of a formulation combining the liposomal encapsulation of RSV and curcumin, aiming at the synergistic improvement of their bioavailability and anti-tumour effect against prostate cancer. They concluded that in vivo oral co-administration of these phytochemicals in prostate-specific PTEN-knockout mice promoted an increase in both compound levels in the serum and prostate tissue, and improved chemoprotective efficacy in prostate cancer, inhibiting cellular growth and inducing apoptosis.

\section{Solid lipid nanoparticles}

Solid lipid nanoparticles (SLN) were first developed in 1991 as an alternative carrier system to 
the existing traditional carriers previously described. These systems endow a lipophilic nature, and are composed of physiological and biodegradable solid lipids and surfactants of low systemic toxicity and low cytotoxicity, most of them commonly used as excipients in commercially available topical cosmetic or pharmaceutical preparations (Pardeike, Hommoss, Müller, 2009; Teskač, Kristl, 2010). Additionally, the small size of the lipid particles used (average particle size below $500 \mathrm{~nm}$ ) ensures a close contact with the stratum corneum, being able to increase the amount of drug penetrating the mucosa or the skin, considerably advantageous for topical delivery.

In pharmaceutics, SLN are feasible for all routes of administration, due to their small size, bioavailability, and excellent physicochemical stability, which provide further protection against the degradation of labile drugs. Their solid lipid matrix enables the incorporation of nonpolar actives, such as RSV, evidencing a higher loading capacity, and also allowing a controlled release of the drug and drug targeting, when supplied over a prolonged period of time and reducing systemic absorption (Pardeike, Hommoss, Müller, 2009; Teskač, Kristl, 2010). Furthermore, these nanocarriers can be transdermal delivered, crossing the keratinocyte barrier and concentrating around nuclei, thereby enhancing the intracellular sustained delivery of RSV, as they can provide benefits by delivering RSV locally, near the nuclear target site, also enabling a faster release of RSV and enhanced cytostatic activity against skin neoplastic cells, without causing significant changes in cell morphology, metabolic activity or cell cycle (Teskač, Kristl, 2010). The loading of the drug molecules can occur in the solid lipid matrix, at the surface of these nanoparticles, or even adsorbing to its surface (hydrophilic periphery). When loaded, RSV is preferably partitioned into the SLN shell, instead of accumulating in the aqueous medium, enabling its initial burst release, in great part due to its lipophilic nature and the presence of three hydroxyl groups, which tend to localize it at the interface in the SLN hydrophilic area. After this stage, the remaining drug incorporated in the SLN matrix is steadily released, in a sustained manner, over a long period of time (Teskač, Kristl, 2010). Another important fact of SLN is related to the possibility of large scale production and the avoidance of organic solvents during preparation, which all contribute to dermal application, as this will probably be the main future application of these nanocarriers.

\section{Other formulations}

Some authors have tried to enhance RSV pharmacokinetic parameters by partially inhibiting its glucuronidation via co-administration with metabolism inhibitors, thereby slowing down its elimination and consequently low bioavailability, prolonging its presence in vivo (Amri et al., 2012). In this context, Johnson et al. (2011) evaluated the use of an alkaloid, piperine, derived from black pepper, to inhibit RSV glucuronidation in vivo. The authors determined the effect of piperine coadministration with RSV on C57BL healthy mice serum levels, by analysing RSV and RSV-3-O- $\beta$-D-glucuronide serum levels at different times. They found that the degree of exposure to RSV was enhanced by $229 \%$, and an increase of $1,554 \%$ in the maximum serum RSV concentration after a single oral administration was observed.

Another alternative might be through the regioselective synthesis of RSV oligomers, largely ignored despite their high biological activity. Snyder, Gollner and Chiriac, (2011) performed a programmable, controlled and potentially scalable synthesis of the RSV family via a three-stage design, and found that, not only the controlled synthesis of higher order RSV oligomers (and potentially the entire class) can be achieved, but also the developed sequences provide opportunities to optimize biological activity and alter physicochemical properties by making analogs otherwise inaccessible from RSV alone.

On the other hand, Burkon and Somoza (2008) suggested the administration of piceid as an alternative to pure compound intake, as they believe that piceid might be enzymatically hydrolysed in the colon, where the intestinal microflora might provide the enzymatic activity to form the trans-RSV aglycone, or inside enterocytes, resulting in the formation of trans-RSV, representing an alternative soluble form for RSV administration. Furthermore, they have also identified up to seven transRSV metabolites (including two new diglucuronides) in plasma and urine from nine healthy volunteers after administration of $85.5 \mathrm{mg}$ of piceid, corresponding to $50 \mathrm{mg}$ of free RSV.

Kobierski et al. (2009) performed RSV nanosuspensions for dermal application, using four different stabilizers and surfactants at concentrations of $1 \%$ to $2 \%$. They have found that all stabilizers investigated yielded stable nanosuspensions at $1 \%$, whereas even a $2 \%$ concentration destabilized the nanosuspensions. They also reported that these nanosuspensions were found to be stable at room temperature for at least 30 days.

\section{FUTURE TRENDS}

Since its discovery, RSV has been shown to exhibit boundless physiological properties which may be beneficial and useful for human health. However, there are 
still several areas that warrant further investigation and clarification, in order to validate RSV activities:

a) Trans-RSV is bound by LDL and human albumin; when assessing RSV plasma concentrations, the bound part should be taken into account as a potential reserve of RSV, as it can be complexed with fatty acids or integrins.

b) The cis-isomer, in spite of being less effective than the trans-isomer, is also an active form, being often overlooked.

c) Conjugated metabolites may contribute for RSV delivery; although information on RSV metabolite activity is sparse, other conjugated polyphenols, which exhibit strong structural homology to RSV, have been shown to exhibit biological activity and improved pharmacokinetics and pharmacodynamics; on the other hand, the deconjugation at certain sites leading to the parent aglycone (RSV) should not be overlooked, as well as the exact nature of the endogenous metabolites.

d) In some studies, several RSV derivatives were reported to exert similar or even greater biological activities than pure RSV, suggesting that not all RSV metabolites have yet been identified nor given plausible biological activity; future insights into the structure-activity relationship of RSV and its derivatives are expected to promote the development of this very promising class of natural compounds into cancer therapeutics and their incorporation in clinical treatments.

e) There is great inter-individual variability in RSV metabolism, so the question remains of what is the fate of the amount of RSV that is not recovered in urine and faeces; furthermore, a large part of the compound may be bound by cell membranes or lipophilic tissue, which can seriously underestimate the free RSV levels in serum, as large amounts of this compound may be deposited in the cellular fraction. RSV effects may not result from the visible plasma fraction, but rather from the RSV cellular fraction which is not assessed.

f) The limited number of foods containing high levels of RSV, such as wine, may lead the search for new strategies to attain this end, so the development of transgenic foods is of particular and great interest.

Nevertheless, several strategies are under investigation in order to focus on the improvement of RSV limitations and/or in vivo effects, from modifying the RSV structural determinants, such as number and position of the $\mathrm{OH}^{-}$groups, intramolecular hydrogen bonding, stereoisomerism and double bond, to the biological effects of RSV metabolites or conjugates. Moreover, some authors also propose the synthesis of RSV oligomers, and several co-workers are exploring various galenic forms as cyclodextrins, solid lipid nanoparticles, liposomes, microspheres, nanosuspensions and others, in order to increase its potential of targeting and sustained delivery at the site of action. Therefore, the possible scenarios for future research include the strategy of combining RSV with compounds that can inhibit the in vivo metabolism of RSV, the use of nanoparticle-mediated delivery, synthesis and/or evaluation of RSV analogs with improved bioavailability, and cautious evaluation of conjugated metabolites of RSV which can be deconjugated at the target organ to stimulate a biological response.

RSV's pharmacological properties support the use of this compound as a promising candidate in chemopreventive and chemotherapeutic strategies, a potential weapon in the effort to lessen the burden of human cancer as a complementary nutritional/ pharmacological biomolecule.

To fully realize the potential of RSV, long-term epidemiologic studies and controlled clinical trials are also necessary for the development of RSV as a standard clinical agent. Safety during long-term administration, combined with its cost and future therapeutic potential, makes it an ideal biomolecule for both prevention and therapy of chronic illnesses, either alone or in combination with other drugs. The incorporation of RSV in the reverse pharmacology is likely to prove Hippocrates quote, 'Let food be thy medicine and medicine be thy food'.

\section{REFERENCES}

AFAQ, F. Natural agents: cellular and molecular mechanisms of photoprotection. Arch. Biochem. Biophys., v.508, n.2, p.144-151, 2011.

AFAQ, F.; ADHAMI, V.M.; AHMAD, N. Prevention of short-term ultraviolet $\mathrm{B}$ radiation-mediated damages by resveratrol in SKH-1 hairless mice. Toxicol. Appl. Pharmacol., v.186, n.1, p.28-37, 2003.

AMRI, A.; CHAUMEIL, J.C.; SFAR, S.; CHARRUEAU, C. Administration of resveratrol: what formulation solutions to bioavailability limitations? J. Control. Release, v.158, n.2, p.182-193, 2012. 
ANSARI, K.; VAVIA, P.; TROTTA, F.; CAVALLI, R. Cyclodextrin-based nanosponges for delivery of resveratrol: in vitro characterisation, stability, cytotoxicity and permeation study. AAPS Pharm. Sci. Tech., v.12, n.1, p.279286, 2011.

ATANACKOVIĆ, M.; POŠA, M.; HEINLE, H.; GOJKOVIĆBUKARICA, L.; CVEJIĆ, J. Solubilization of resveratrol in micellar solutions of different bile acids. Colloids Surf B: Biointerfaces, v.72, n.1, p.148-154, 2009.

ATANACKOVIĆ, M.T.; GOJKOVIĆ-BUKARICA, L.C.; CVEJIĆ, J.M. Improving the low solubility of resveratrol. BMC Pharmacol. Toxicol., v.13, suppl.1, p.A25, 2012.

AUGUSTIN, M.A.; SANGUANSRI, L.; LOCKETT, T. Nanoand micro-encapsulated systems for enhancing the delivery of resveratrol. Ann. N. Y. Acad. Sci., v.1290, p.107-112, 2013.

BASAVARAJ, S.; BETAGERI, G.V. Improved oral delivery of resveratrol using proliposomal formulation: investigation of various factors contributing to prolonged absorption of unmetabolized resveratrol. Expert. Opin. Drug Deliv., v.11, n.4, p.493-503, 2014.

BAUR, J.A.; PEARSON, K.J.; PRICE, N.L.; JAMIESON, H.A.; LERIN, C.; KALRA, A.; PRABHU, V.V.; ALLARD, J.S.; LOPEZ-LLUCH, G.; LEWIS, K.; Pistell, P.J.; POOSALA, S.; BECKER, K.G.; BOSS, O.; GWINN, D.; WANG, M.; RAMASWAMY, S.; FISHBEIN, K.W.; SPENCER, R.G.; LAKATTA, E.G.; LE COUTEUR, D.; SHAW, R.J.; NAVAS, P.; PUIGSERVER, P.; INGRAM, D.K.; DE CABO, R.; SINCLAIR, D.A. Resveratrol improves health and survival of mice on a high-calorie diet. [Research Support, N.I.H., Extramural Research Support, Non-U.S. Gov't]. Nature, v.444, n.7117, p.337-342, 2006.

BHAT, K.; PEZZUTO, J.M. Cancer chemopreventive activity of resveratrol. Ann. N. Y. Acad. Sci., v.957, p.210-229, 2002.

BHATT, J.K.; THOMAS, S.; NANJAN, M.J. Resveratrol supplementation improves glycemic control in type 2 diabetes mellitus. Nutr. Res., v.32, n.7, p.537-541, 2012

BISHAYEE, A. Cancer prevention and treatment with resveratrol: from rodent studies to clinical trials. Cancer Prev. Res. (Phila), v.2, n.5, p.409-418, 2009.
BO, S.; CICCONE, G.; CASTIGLIONE, A.; GAMBINO, R.; DE MICHIELI, F.; VILLOIS, P.; DURAZZO, M.; CAVALLO-PERIN, P.; CASSADER, M. Anti-inflammatory and antioxidant effects of resveratrol in healthy smokers a randomized, double-blind, placebo-controlled, cross-over trial. Curr. Med. Chem., v.20, n.10, p.1323-1331, 2013.

BOLKO, K.; ZVONAR, A.; GAŠPERLIN, M. Mixed lipid phase SMEDDS as an innovative approach to enhance resveratrol solubility. Drug Dev. Ind. Pharm., v.40, n.1, p.102-109, 2014.

BU, L.; GAN, L.C.; GUO, X.Q.; CHEN, F.Z.; SONG, Q.; QIZHAO; GOU, X.J.; HOU, S.X.; YAO, Q. Trans-resveratrol loaded chitosan nanoparticles modified with biotin and avidin to target hepatic carcinoma. Int. J. Pharm., v.452, n.1-2, p.355-362, 2013.

BURKON, A.; SOMOZA, V. Quantification of free and proteinbound trans-resveratrol metabolites and identification of trans-resveratrol-C/O-conjugated diglucuronides - Two novel resveratrol metabolites in human plasma. Mol. Nutr. Food Res., v.52, n.5, p.549-557, 2008.

CADDEO, C.; TESKAČ, K.; SINICO, C.; KRISTL, J. Effect of resveratrol incorporated in liposomes on proliferation and UV-B protection of cells. Int. J. Pharm., v.363, n.1-2, p.183-191, 2008.

CHEN, S.; ZHAO, X.; RAN, L.; WAN, J.; WANG, X.; QIN, Y.; SHU, F.; GAO, Y.; YUAN, L.; ZHANG, Q.; MI, M. Resveratrol improves insulin resistance, glucose and lipid metabolism in patients with non-alcoholic fatty liver disease: a randomized controlled trial. Dig. Liver Dis., v.47, n.3, p.226-232, 2015.

COLLADO, A.; CORBALÁN, N.; HOMOLYA, L.; MORERO, R.; MINAHK, C.; Resveratrol modulates ATPase activity of liposome-reconstituted ABCG1. FEBS Lett., v.587, n.15, p.2359-2363, 2013.

COTTART, C.-H.; NIVET-ANTOINE, V.; LAGUILLIERMORIZOT, C.; BEAUDEUX, J.-L. Resveratrol bioavailability and toxicity in humans. Mol. Nutr. Food Res., v.54, n.1, p.7-16, 2010.

COUNET, C.; CALLEMIEN, D.; COLLIN, S. Chocolate and cocoa: new sources of trans-resveratrol and trans-piceid. Food Chem., v.98, n.4, p.649-657, 2006 
DAS, S.; LIN, H.S.; HO, P.C.; NG, K.Y. The impact of aqueous solubility and dose on the pharmacokinetic profiles of resveratrol. Pharm. Res., v.25, n.11, p.2593-2600, 2008.

DELMAS, D.; AIRES, V.; LIMAGNE, E.; DUTARTRE, P.; MAZUÉ, F.; GHIRINGHELLI, F.; LATRUFFE, N. Transport, stability, and biological activity of resveratrol. Ann. N. Y. Acad. Sci., v.1215, p.48-59, 2011.

EROĞLU, İ.; GÖKÇE, E.H.; TSAPIS, N.; TANRIVERDI, S.T.; GÖKÇE, G.; FATTAL, E.; ÖZER, Ö. Evaluation of characteristics and in vitro antioxidant properties of RSV loaded hyaluronic acid-DPPC microparticles as a wound healing system. Colloids Surf. B Biointerfaces, v.126, p.50-57, 2015.

ESPÍN, J.C.; GARCÍA-CONESA, M.T.; TOMÁS-BARBERÁN, F.A. Nutraceuticals: facts and fiction. Phytochemistry, v.68, n.22-24, p.2986-3008, 2007.

GREEN, C. L.; KHAVARI, P.A. Targets for molecular therapy of skin cancer. Semin. Cancer Biol., v.14, n.1, p.63-69, 2004.

HALILBASIC, E., CLAUDEL, T., TRAUNER, M. Bile acid transporters and regulatory nuclear receptors in the liver and beyond. J. Hepatol, v.58, n.1, p.155-168, 2013.

HARIKUMAR, K.B.; AGGARWAL, B.B. Resveratrol: a multitargeted agent for age-associated chronic diseases. Cell Cycle, v.7, n.8, p.1020-1035, 2008.

HSIEH, T.-C.; WU, J.M. Resveratrol: biological and pharmaceutical properties as anticancer molecule. BioFactors, v.36, n.5, p.360-369, 2010.

HUANG, X.; ZHU, H.-L. Resveratrol and its analogues: promising antitumor agents. Anticancer Agents Med. Chem., v.11, n.5, p.479-490, 2011.

HUNG, C.-F.; LIN, Y.-K.; HUANG, Z.-R.; FANG, J.-Y. Delivery of resveratrol, a red wine polyphenol, from solutions and hydrogels via the skin. Biol. Pharm. Bull., v.31, n.5, p.955-962, 2008.

ISSUREE, P.D.A.; PUSHPARAJ, P.N.; PERVAIZ, S.; MELENDEZ, A.J. Resveratrol attenuates C5a-induced inflammatory responses in vitro and in vivo by inhibiting phospholipase $\mathrm{D}$ and sphingosine kinase activities. FASEB $J .$, v.23, n.8, p.2412-2424, 2009.
JANG, M.; LINING, C.; UDEANI, G.; SLOWING, K.; THOMAS, C.; BEECHER, C.; PEZZUTO, J. Cancer chemopreventive activity of resveratrol, a natural product derived from grapes. Science, v.275, n.5297, p.218-220, 1999.

JOHNSON, J.J.; NIHAL, M.; SIDDIQUI, I.A.; SCARLETT, C.O.; BAILEY, H.H.; MUKHTAR, H.; AHMAD, N. Enhancing the bioavailability of resveratrol by combining it with piperine. Mol. Nutr. Food Res., v.55, n.8, p.11691176, 2011.

JOSEPH, J.A.; FISHER, D.R.; CHENG, V.; RIMANDO, A.M.; SHUKITT-HALE, B. Cellular and behavioral effects of stilbene resveratrol analogues: implications for reducing the deleterious effects of aging. J. Agric. Food. Chem., v.56, n.22, p.10544-10551, 2008.

KHAN, A.; ALJARBOU, A.N.; ALDEBASI, Y.H.; FAISAL, S.M.; KHAN, M.A. Resveratrol suppresses the proliferation of breast cancer cells by inhibiting fatty acid synthase signaling pathway. Cancer Epidemiol., v.38, n.6, p.765772, 2014.

KIM, A.L.; SNYDER, S.A. Could resveratrol, an ingredient in red wine, prevent skin cancer? Skin Touch, n.2, p.1-8, 2010.

KIM, A.L.; ZHU, Y.; ZHU, H.; HAN, L.; KOPELOVICH, L.; BICKERS, D.R.; ATHAR, M. Resveratrol inhibits proliferation of human epidermoid carcinoma A431 cells by modulating MEK1 and AP-1 signalling pathways. Exp. Dermatol., v.15, n.7, p.538-546, 2006.

KIM, K.H.; BACK, J.H.; ZHU, Y.; ARBESMAN, J.; ATHAR, M.; KOPELOVICH, L.; BICKERS, D.R. Resveratrol targets transforming growth factor-beta2 signaling to block UV-induced tumor progression. J. Invest. Dermatol., v.131, n.1, p.195-202, 2011.

KOBIERSKI, S.; OFORI-KWAKYE, K.; LLER, R.H.; KECK, C.M. Resveratrol nanosuspensions for dermal application production, characterization, and physical stability. Pharmazie, v.64, n.11, p.741-747, 2009.

KOSTYUK, V.A.; POTAPOVICH, A.I.; LULLI, D.; STANCATO, A.; DE LUCA, C.; PASTORE, S.; KORKINA, L. Modulation of human keratinocyte responses to solar uv by plant polyphenols as a basis for chemoprevention of non-melanoma skin cancers. Curr. Med. Chem., v.20, n.7, p.869-879, 2013. 
KUNDU, J.K.; SURH, Y.-J. Cancer chemopreventive and therapeutic potential of resveratrol: mechanistic perspectives. Cancer Lett., v.269, n.2, p.243-261, 2008.

\section{LAGOUGE, M.; ARGMANN, C.; GERHART-HINES, Z.;} MEZIANE, H.; LERIN, C.; DAUSSIN, F.; AUWERX, J. Resveratrol improves mitochondrial function and protects against metabolic disease by activating SIRT 1 and PGC- $1 \alpha$. Cell, v.127, n.6, p.1109-1122, 2006.

LÓPEZ-NICOLÁS, J.M.; GARCÍA-CARMONA, F. Rapid, simple and sensitive determination of the apparent formation constants of trans-resveratrol complexes with natural cyclodextrins in aqueous medium using HPLC. Food Chem., v.109, n.4, p.868-875, 2008.

LÓPEZ-NICOLÁS, J.M.; RODRIGUEZ-BONILLA, P.; GARCIA-CARMONA, F. Complexation of pinosylvin, an analogue of resveratrol with high antifungal and antimicrobial activity, by different types of cyclodextrins. J. Agric. Food Chem., v.57, n.21, p.10175-10180, 2009.

LU, Z.; CHENG, B.; HU, Y.; ZHANG, Y.; ZOU, G. Complexation of resveratrol with cyclodextrins: Solubility and antioxidant activity. Food Chem., v.113, n.1, p.17-20, 2009.

LUCAS-ABELLÁN, C.; FORTEA, I.; LÓPEZ-NICOLÁS, J.M.; NÚÑEZ-DELICADO, E. Cyclodextrins as resveratrol carrier system. Food Chem., v.104, n.1, p.39-44, 2007.

LUCAS-ABELLÁN, C.; MERCADER-ROS, M.T.; ZAFRILLA, M.P.; GABALDÓN, J.A.; NÚÑEZDELICADO, E. Comparative study of different methods to measure antioxidant activity of resveratrol in the presence of cyclodextrins. Food Chem. Toxicol., v.49, n.6, p.12551260, 2011.

MEHNERT, W.; MÄDER, K. Solid lipid nanoparticles: production, characterization and applications. Adv. Drug Dev. Rev., v.47, n.2-3, p.165-196, 2001.

MORAES, F.P.; COLLA, L.M. Alimentos funcionais e nutracêuticos: definições, legislação e benefícios à saúde. Rev. Eletron. Farm., v.3, p.109-122, 2006.

MURIAS, M.; JÄGER, W.; HANDLER, N.; ERKER, T.; HORVATH, Z.; SZEKERES, T.; GILLE, L. Antioxidant, prooxidant and cytotoxic activity of hydroxylated resveratrol analogues: structure-activity relationship. Biochem. Pharmacol., v.69, n.6, p.903-912, 2005.
MUZZIO, M.; HUANG, Z.H.; HU, S.C.; JOHNSON, W.D.; MCCORMICK, D.L.; KAPETANOVIC, I.M. Determination of resveratrol and its sulfate and glucuronide metabolites in plasma by LC-MS/MS and their pharmacokinetics in dogs. J. Pharm. Biomed. Anal., v.59, p.201-208, 2012.

NAM, J.-B.; RYU, J.-H.; KIM, J.-W.; CHANG, I.-S.; SUH, K.D. Stabilization of resveratrol immobilized in monodisperse cyano-functionalized porous polymeric microspheres. Polymer, v.46, n.21, p.8956-8963, 2005.

NARAYANAN, N.K.; NARGI, D.; RANDOLPH, C.; NARAYANAN, B.A. Liposome encapsulation of curcumin and resveratrol in combination reduces prostate cancer incidence in PTEN knockout mice. Int. J. Cancer, v.125, n.1, p.1-8, 2009.

NDIAYE, M.; PHILIPPE, C.; MUKHTAR, H.; AHMAD, N. The grape antioxidant resveratrol for skin disorders: Promise, prospects, and challenges. Arch. Biochem. Biophys., v.508, n.2, p.164-170, 2011.

NEVES, A.R.; LÚCIO, M.; MARTINS, S.; LIMA, J.L.; REIS, S. Novel resveratrol nanodelivery systems based on lipid nanoparticles to enhance its oral bioavailability. Int. $J$. Nanomedicine, v.8, p.177-187, 2013.

ORHAN, N.; ASLAN, M.; ORHAN, D.D.; ERGUN, F.; YEŞILADA, E. In-vivo assessment of antidiabetic and antioxidant activities of grapevine leaves (Vitis vinifera) in diabetic rats. J. Ethnopharmacol., v.108, n.2, p.280-286, 2006.

OVESNA, Z.; KOZICS, K.; BADER, Y.; SAIKO, P.; HANDLER, N.; ERKER, T.; SZEKERES, T. Antioxidant activity of resveratrol, piceatannol and 3,3',4,4',5,5'-hexahydroxytrans-stilbene in three leukemia cell lines. Oncol. Rep., v.16, n.3, p.617-624, 2006.

PARDEIKE, J.; HOMMOSS, A.; MÜLLER, R.H. Lipid nanoparticles (SLN, NLC) in cosmetic and pharmaceutical dermal products. Int. J. Pharm., v.366, n.1-2, p.170-184, 2009.

PAULO, L.; DOMINGUES, F.; QUEIROZ, J.A.; GALLARDO, E. Development and validation of an analytical method for the determination of trans- and cis-resveratrol in wine: analysis of its contents in 186 Portuguese red wines. $J$. Agric. Food Chem., v.59, n.6, p.2157-2168, 2011. 
PENG, H.; XIONG, H.; LI, J.; XIE, M.; LIU, Y.; BAI, C.; CHEN, L. Vanillin cross-linked chitosan microspheres for controlled release of resveratrol. Food Chem., v.121, n.1, p.23-28, 2010.

PEZZUTO, J.M. The phenomenon of resveratrol: redefining the virtues of promiscuity. Ann. N. Y. Acad. Sci., v.1215, p.123-130, 2011.

PIROLA, L.; FRÖJDÖ, S. Resveratrol: one molecule, many targets. IUBMB Life, v.60, n.5, p.323-332, 2008.

PROENÇA DA CUNHA, A. Compostos fenólicos: características e origem biossintética. In: PROENÇA DA CUNHA, A. (Ed.). Farmacognosia e fitoquímica. Lisboa: Fundação Calouste Gulbenkian, 2005. p.211-216.

RAGAB, A.S.; VAN FLEET, J.; JANKOWSKI, B.; PARK, J.H.; BOBZIN, S.C. Detection and quantitation of resveratrol in tomato fruit (Lycopersicon esculentum Mill.). J. Agric. Food Chem., v.54, n.19, p.7175-7179, 2006.

REAGAN-SHAW, S.; AFAQ, F.; AZIZ, M. H.; AHMAD, N. Modulations of critical cell cycle regulatory events during chemoprevention of ultraviolet B-mediated responses by resveratrol in SKH-1 hairless mouse skin. Oncogene, v.23, n.30, p.5151-5160, 2004.

ROTCHES-RIBALTA, M.; ANDRES-LACUEVA, C.; ESTRUCH, R.; ESCRIBANO, E.; URPI-SARDA, M. Pharmacokinetics of resveratrol metabolic profile in healthy humans after moderate consumption of red wine and grape extract tablets. Pharmacol. Res., v.66, n.5, p.375-382, 2012.

SANNA, V.; SIDDIQUI, I.A.; SECHI, M.; MUKHTAR, H. Resveratrol-loaded nanoparticles based on poly(epsiloncaprolactone) and poly(D,L-lactic-co-glycolic acid)poly(ethylene glycol) blend for prostate cancer treatment. Mol. Pharm., v.10, n.10, p.3871-3881, 2013.

SANTOS, A.C.; VEIGA, F.; RIBEIRO, A.J. New delivery systems to improve the bioavailability of resveratrol. Expert. Opin. Drug Deliv., v.8, n.8, p.973-990, 2011.

SESSA, M.; BALESTRIERI, M.L.; FERRARI, G.; SERVILLO, L.; CASTALDO, D.; D’ONOFRIO, N.; DONSİ, F.; TSAO, R. Bioavailability of encapsulated resveratrol into nanoemulsion-based delivery systems. Food Chem., v.15, n.147, p.42-50, 2014.
SHI, G.; RAO, L.; YU, H.; XIANG, H.; YANG, H.; JI, R. Stabilization and encapsulation of photosensitive resveratrol within yeast cell. Int. J. Pharm., v.349, n.1-2, p.83-93, 2008.

SHUKLA, Y.; SINGH, R. Resveratrol and cellular mechanisms of cancer prevention. Ann. N. Y. Acad. Sci., v.1215, p.1-8, 2011.

SINGH, G.; PAI, R.S. In vitro and in vivo performance of supersaturable self-nanoemulsifying system of transresveratrol. Art. Cells Nanomed. Biotechnol., v.21, p.1-7, 2014.

SMOLIGA, J.M.; BAUR, J.A.; HAUSENBLAS, H.A. Resveratrol and health - a comprehensive review of human clinical trials. Mol. Nutr. Food Res., v.55, n.8, p.1129-1141, 2011.

SNYDER, S.A.; GOLLNER, A.; CHIRIAC, M.I. Regioselective reactions for programmable resveratrol oligomer synthesis. Nature, v.474, p.461-466, 2011.

SVOBODOVÁ, A.; PSOTOVÁ, J.; WALTEROVÁ, D. Natural phenolics in the prevention of UV-induced skin damage. A review. [Research Support, Non-U.S. Gov’t Review]. Biomed. Pap. Med. Fac. Univ. Palacky Olomouc Czech Repub., v.147, n.2, p.137-145, 2003.

SYED, D.N.; MUKHTAR, H. Botanicals for the prevention and treatment of cutaneous melanoma. Pigment. Cell Melanoma Res., v.24, n.4, p.688-702, 2011.

TESKAČ, K.; KRISTL, J. The evidence for solid lipid nanoparticles mediated cell uptake of resveratrol. Int. J. Pharm., v.390, n.1, p.61-69, 2010.

VYAS, A.; SARAF, S. Cyclodextrin based novel drug delivery systems. J. Incl. Phenom. Macrocycl. Chem., v.62, n.1-2, p.23-42, 2008.

ZU, Y.; ZHANG, Y.; WANG, W.; ZHAO, X.; HAN, X.; WANG, K.; GE, Y. Preparation and in vitro/in vivo evaluation of resveratrol-loaded carboxymethyl chitosan nanoparticles. Drug Deliv., v.11, p.1-11, 2014.

Received for publication on $13^{\text {th }}$ January 2015 Accepted for publication on $09^{\text {th }}$ June 2015 
